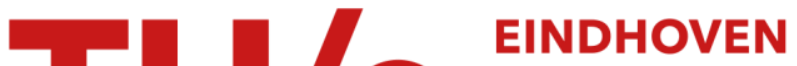 UNIVERSITY OF TECHNOLOGY
}

\section{Measurements of particle residence time distributions in a co- current spray dryer}

Citation for published version (APA):

Kieviet, F. G., \& Kerkhof, P. J. A. M. (1995). Measurements of particle residence time distributions in a cocurrent spray dryer. Drying Technology, 13(5-7), 1241-1248. https://doi.org/10.1080/07373939508917019

DOI:

10.1080/07373939508917019

Document status and date:

Published: 01/01/1995

\section{Document Version:}

Publisher's PDF, also known as Version of Record (includes final page, issue and volume numbers)

\section{Please check the document version of this publication:}

- A submitted manuscript is the version of the article upon submission and before peer-review. There can be important differences between the submitted version and the official published version of record. People interested in the research are advised to contact the author for the final version of the publication, or visit the $\mathrm{DOI}$ to the publisher's website.

- The final author version and the galley proof are versions of the publication after peer review.

- The final published version features the final layout of the paper including the volume, issue and page numbers.

Link to publication

\section{General rights}

Copyright and moral rights for the publications made accessible in the public portal are retained by the authors and/or other copyright owners and it is a condition of accessing publications that users recognise and abide by the legal requirements associated with these rights.

- Users may download and print one copy of any publication from the public portal for the purpose of private study or research.

- You may not further distribute the material or use it for any profit-making activity or commercial gain

- You may freely distribute the URL identifying the publication in the public portal.

If the publication is distributed under the terms of Article 25fa of the Dutch Copyright Act, indicated by the "Taverne" license above, please follow below link for the End User Agreement:

www.tue.nl/taverne

Take down policy

If you believe that this document breaches copyright please contact us at:

openaccess@tue.nl

providing details and we will investigate your claim. 
DRYING TECHNOLOGY, 13(5-7), 1241-1248 (1995)

\title{
MEASUREMENTS OF PARTICLE RESIDENCE TIME DISTRIBUTIONS IN A CO-CURRENT SPRAY DRYER
}

\author{
Frank Kieviet and Piet J.A.M. Kerkhof \\ Laboratory of Separations Technology, Department of Chemical \\ Engineering, Eindhoven University of Technology, P.O.Box 513-FT, \\ NL-5600 MB Eindhoven, The Netherlands
}

Key Words: particulates; spray drying

\begin{abstract}
Measurements of particle residence time distributions by means of tracer analysis were done in a co-current pilot plant spray dryer operated with a pressure-nozzle. A system is described for injecting tracer into the feedstream just before the nozzle. Tracer concentrations were measured in two product streams: the tower product stream (mean particle size 134 microns) and the cyclone product stream (mean particle size 67 microns).

The measurements show a very wide range of residence times: some particles have residence times shorter than 3 seconds, others have residence times longer than 10 minutes. The median of the distribution is $58.5 \mathrm{~s}$ for the tower product stream and $42.2 \mathrm{~s}$ for the cyclone product stream.
\end{abstract}

\section{INTRODUCTION}

The residence time distribution of particles is a key characteristic in a spray drying process since it determines the time particles are in contact with hot air. It is therefore one of the most important factors that influence processes within the particles that are non-linear in time, such as moisture loss (the actual drying), thermal degradation etc.

In literature it is generally assumed that the residence time distribution of the particles is the same as that of the drying air. See for instance Masters (1). Although 
many articles have been published on measurements of residence time distributions of the drying air (see for instance Place et al. (2), Keey and Pham (3), Paris et al. (4) and Ade-John et al. (5)), only one article is known to us where a residence time distribution of the particles was measured: that of Pham and Keey (ㅁ).

\section{BACKGROUND}

The residence time distribution of particles will generally be not the same as that of the drying air. This may come from the fact that particles cannot follow the air because of their inertia and density. Another mechanism that will lengthen the particles' residence time compared to the drying air residence time will be caused by the fact that particles may end their air-borne lives when they are deposited on the wall where they will slide down slowly to the product outlet. The transport along the wall will generally be stimulated by outside actions such as hitting the wall with electrical hammers or devices such as air sweepers or brushes. Since wall temperatures will be quite high, when a particle hits the wall it does not mean that processes such as drying and especially thermal degradation come to a full stop, although mass transfer will deteriorate. Measurements of particle residence time distributions should therefore not be limited to particles that are airborne continuously.

Residence time distributions of particles in spray drying operations can be measured by disturbing the feed in some way and measuring the response in the product stream. Such a disturbance may be applied to the flowrate or the composition of the feed on the condition that the conditions in the drying chamber that affect the residence time distribution are not changed.

When measuring the response to a disturbance in the feed flowrate, the disturbance should be quite large to distinguish the actual response from the noise. A large change in the feed flow rate affects the total evaporation in the drying chamber and thus the temperature and air flow. When using a pressure nozzle to atomise the feed, the particle size distribution is affected as well. A disturbance in the feed flow rate is therefore not an accurate method for measuring the residence time distribution.

As long as the change in feed composition is small, as is the case of a tracer component, spray drying conditions (temperature etc.) are not affected and thus offers better opportunities for measurements. Another advantage of using tracers is that the residence time distribution can be measured as function of the particle size. This is important since large particles may have other residence times than small particles.

A tracer must meet the following conditions: the compound must be soluble in the feed, must be easily detectable in small quantities and should not change during the spray drying process (i.e. degrade or evaporate).

\section{EXPERIMENT}

In our experiments a tracer was injected into the feed in the form of a short pulse. 
The product was collected at the outlet and the tracer concentration in the product was measured.

The dryer used in our investigations is a Niro Atomizer standard pilot-plant cocurrent spray dryer. See figure 1. The dryer is equipped with various temperature, humidity and flow measurement devices. Two electrical hammers hit the cone every two seconds. The feed is atomised by a centrifugal pressure-nozzle (Spraying Systems Co: SX-type, orifice no. 70 hole diameter $0.71 \mathrm{~mm}$, core no. 416 , spray angle $70^{\circ}$ ). The atomisation pressure was 75 bar. The air inlet-temperature was $195^{\circ} \mathrm{C}$, the outlet temperature $105^{\circ} \mathrm{C}$, the flowrate approximately $1040 \mathrm{~m}^{3} / \mathrm{h}$. The feed was an aqueous maltodextrin solution ( 42.8 weight $\%$ d.s.); the flow rate was $52.5 \mathrm{~kg} / \mathrm{h}(\approx 44.3 \mathrm{l} / \mathrm{h})$. The feed pump is a three-plunger positive displacement pump. The dried product is discharged via rotary valves at the bottom of the cone and the cyclone. The product flow rate from the tower was $15.8 \mathrm{~kg} / \mathrm{h}$, that from the cyclone $7.8 \mathrm{~kg} / \mathrm{h}(67 \%$ and $33 \%$ respectively).

The particle size distribution of the spray dried product was measured by sieving. Seven sieves were used (Endecotts, apertures 250, 180, 150,125, 106, 75 and $53 \mu \mathrm{m}$ ). The results were fitted into a Rosin-Rammler distribution by non-linear regression. The results are depicted in figure 3.

For injecting the tracer into the feed without disturbing the flow rate, a special injection system had to be developed. The system consists of a set of valves installed just before the nozzle. See figure 2.

For loading the tracer, valves 2 and 3 are closed. The tube between valves 2 and 3 (called the sampleloop) is now pressureless so valve 4 can be opened (valve 4 actually is a bolt to avoid dead volume). The liquid in the sampleloop is replaced with tracer-solution. Next, valve 4 is closed and valve 2 is opened. Valve 1 is closed partially, causing an extra pressure increase of about 10 bar. When valve 3 is opened, the liquid will flow through the sampleloop because of the resistance caused by valve 1 , carrying the sample solution with it. In this way the tracer is injected without causing any disturbance to the flow rate.

The volume of sampleloop is approximately $10.5 \mathrm{ml}$. Assuming plugflow the pulsewidth is therefore approximately $1 \mathrm{~s}$. The volume of the tube between the nozzle and valve 3 is approximately $13 \mathrm{ml}$ and will cause a delay in the injection of about $1 \mathrm{~s}$. This delay has been compensated for in the processing of the results.

The tracer used was Rhodamine-WT (Polysciences Inc. Cat \#19922). This is a water soluble substance that has an intense red colour. The thermal stability was tested by means of Thermal Gravimetric Analysis and Differential Thermal Analysis. It was found that the rhodamine did neither degrade nor evaporate in measurable amounts.

The tracer solution that was injected consisted of the maltodextrin solution described above and a small amount of rhodamine. The concentration of maltodextrin was the same as in the normal feed; the concentration of rhodamine was $1.8 \%$ by weight.

The concentration of rhodamine in the dried powder was measured by dissolving a known quantity of powder in a known quantity of water. The absorbance of the solution was measured at $557 \mathrm{~nm}$ by means of a spectrophotometer (Pharmacia Novaspec II). From this the concentration could be calculated. 


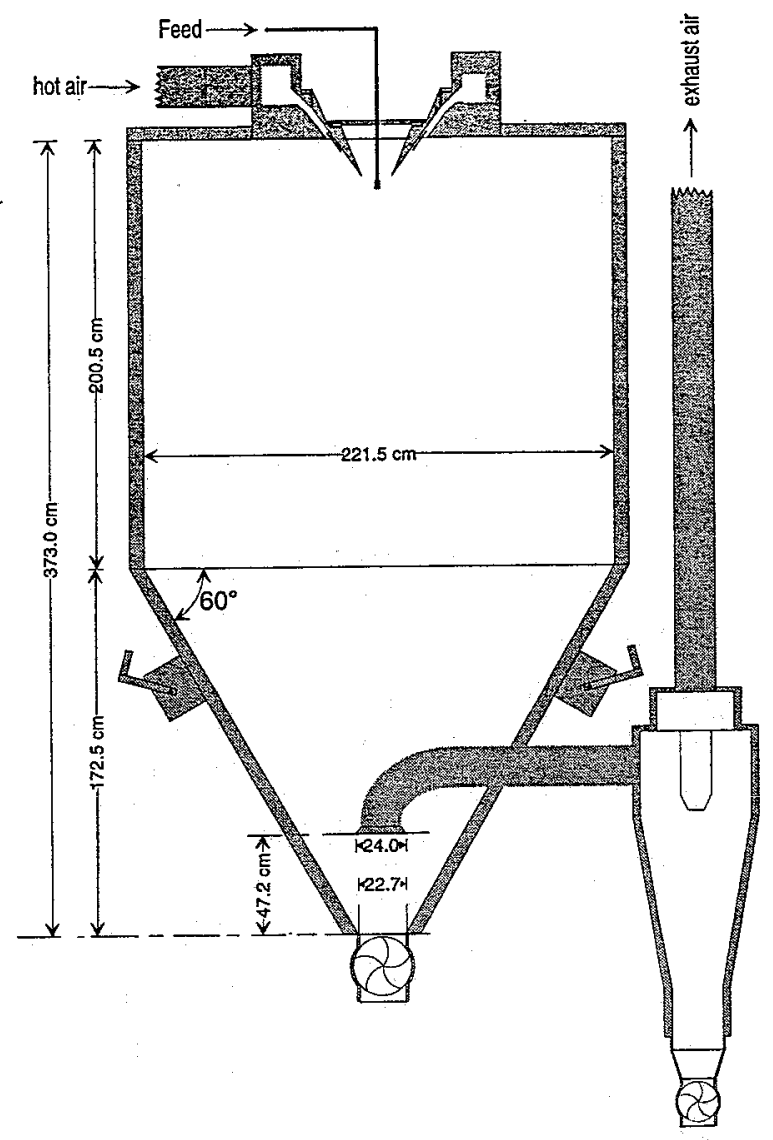

FIGURE 1: spray dryer

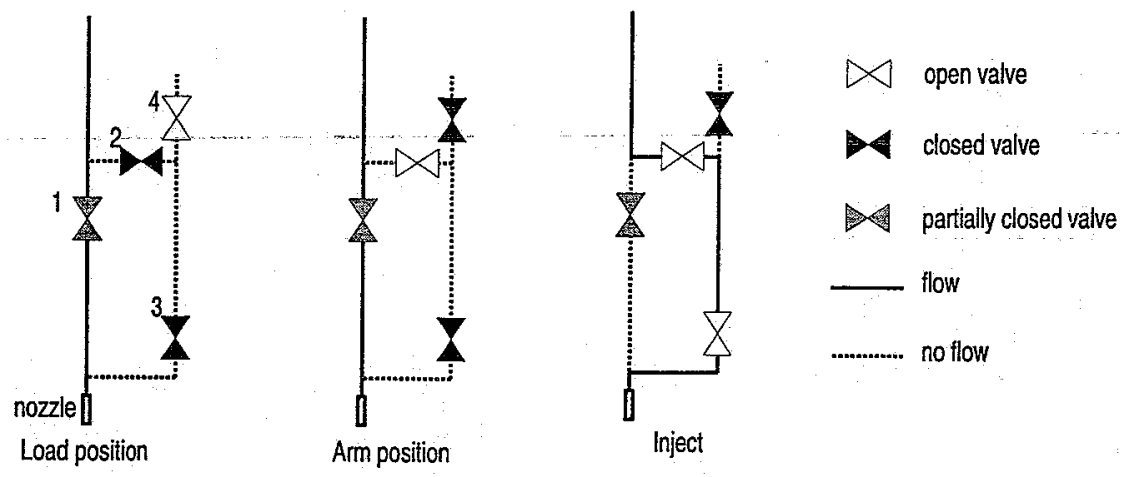




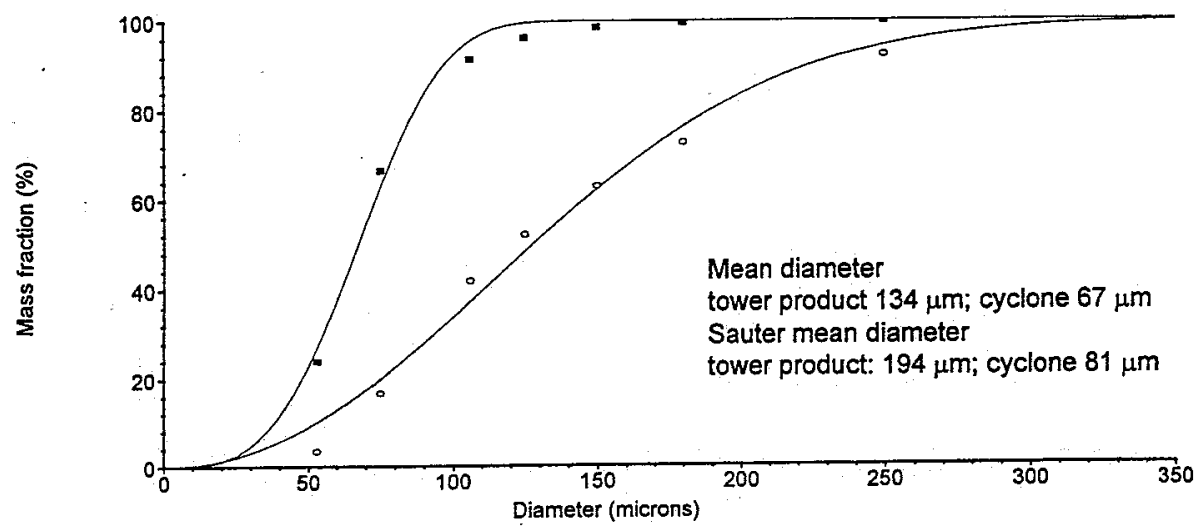

FIGURE 3: Particle size distributions of product streams experiments $(\square=$ cyclone product stream; $0=$ tower product stream)

The rotary dischargers that are installed under the cone and the cyclone rotate at a speed of 27.2 and $53.7 \mathrm{rpm}$ respectively. Assuming the discharges have to make half a revolution, the delay will be 1.1 and $0.56 \mathrm{~s}$ respectively. This delay has been compensated for in the processing of the results.

Under the cone and cyclone vibrating funnels were installed. Under the funnels a conveyor belt was installed on which small trays were placed. The conveyor belt moved under the funnels at a speed of approximately one tray every two seconds. The trays were collected at the end of the conveyor belt and their contents were to be analysed.

\section{RESULTS}

A number of experiments were carried out. Of two experiments the concentration of tracer as function of time ( $E$-curve) is depicted in figure 4 . This upper chart includes 283 analysed samples. Because of the large amount of time involved in analysing the samples, some samples were skipped in the lower chart (213 datapoints).

Because the product flow rate is fluctuating in time (probably caused by the unsteady sliding of the product that is deposited on the wall), all product should be collected and analysed for calculating the $F$-curve. The $F$-curve is here defined as:

$$
F_{i}=\frac{1}{\sum_{j=1}^{n} c_{j} \cdot m_{j}} \cdot \sum_{j=1}^{i} c_{j} \cdot m_{j}
$$

The $F$-curve is depicted in figure 5. This curve is used to calculate some percentiles $p$, defined as the time $t$ it takes before $p$ percent of the tracer has left the dryer. The median residence time is equal to $p=50 \%$. See table 1 . 

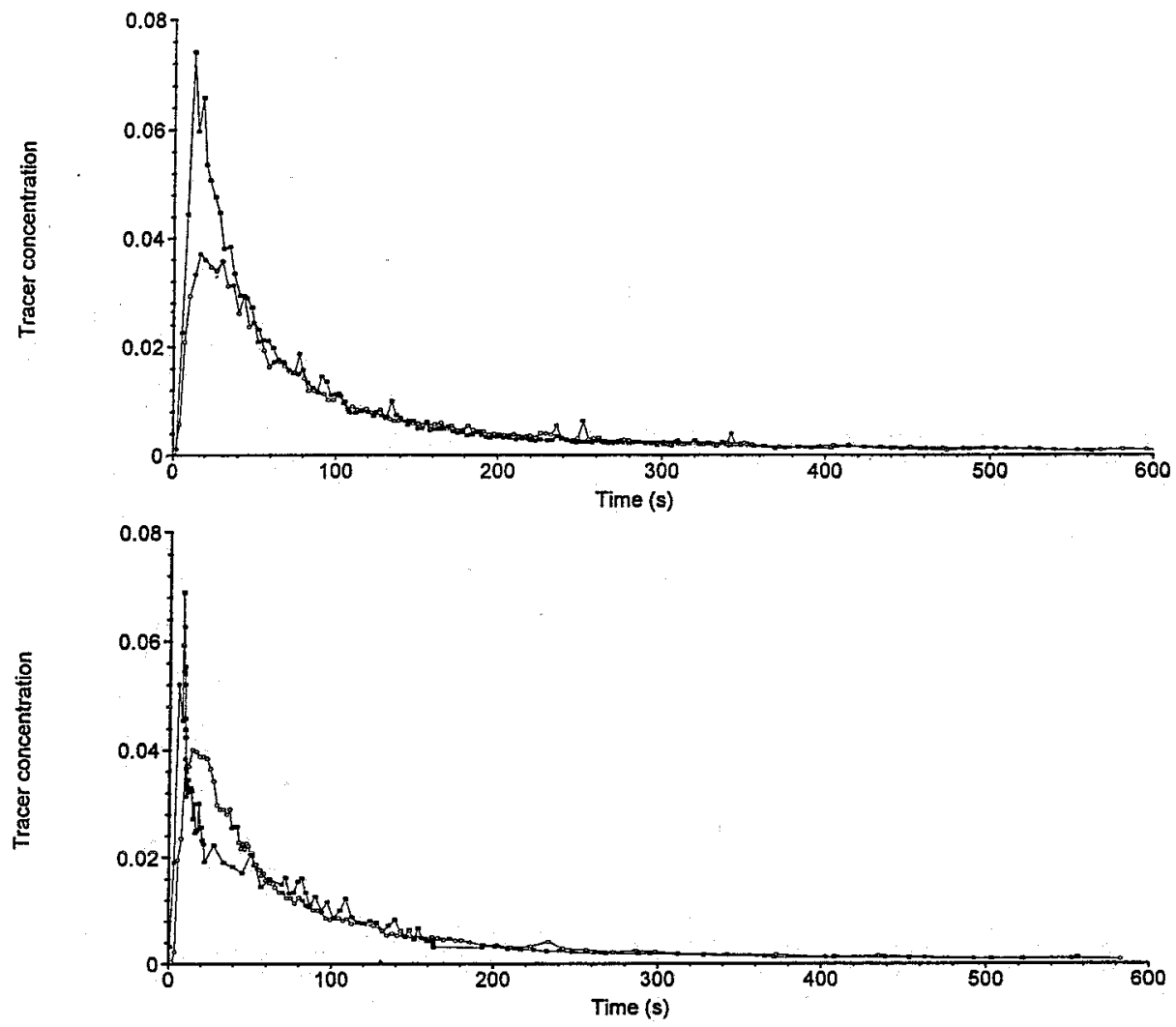

FIGURE 4: Concentration of tracer in dried powder as function of time for two experiments $(\mathbf{m}=$ cyclone product stream; $0=$ tower product stream $)$

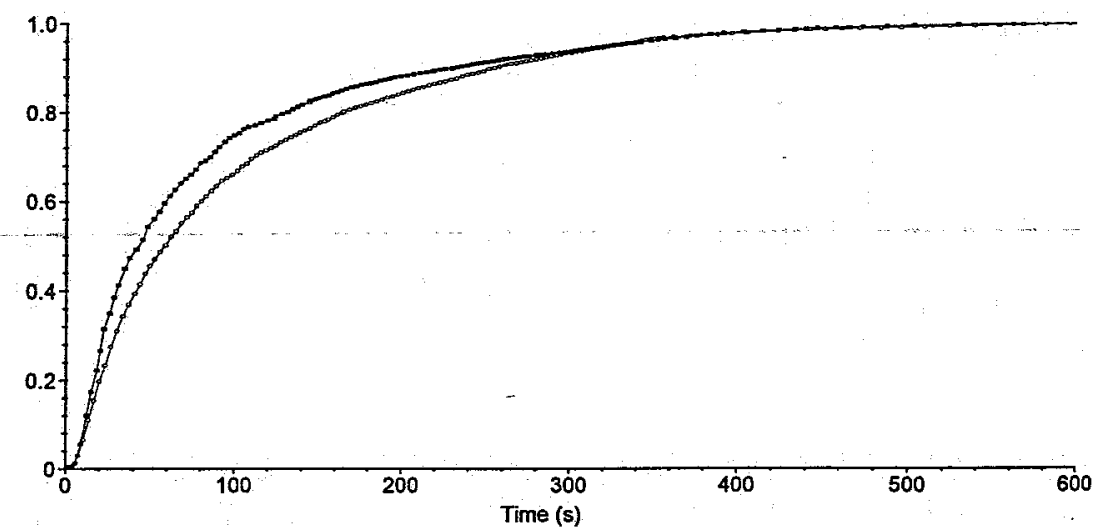

FIGURE 5: F-curve ( $=$ cyclone product stream; $0=$ tower product stream) 
TABLE 1: percentiles of productstreams tower and cyclone

\begin{tabular}{|ccc|ccc|}
\hline$p$ & time tower $(\mathrm{s})$ & time cyclone $(\mathrm{s})$ & $p$ & time tower $(\mathrm{s})$ & time cyclone $(\mathrm{s})$ \\
\hline 5 & 10.3 & 8.5 & 50 & 58.5 & 42.8 \\
10 & 13.5 & 11.3 & 60 & 80.5 & 59.3 \\
20 & 20.1 & 16.9 & 70 & 111.7 & 86.2 \\
30 & 28.7 & 21.9 & 80 & 165.5 & 131.2 \\
40 & 41.7 & 29.8 & 90 & 255.5 & 230.5 \\
\hline
\end{tabular}

Because of the long tailing at which the concentration could not be measured very accurately, the first (average residence time, tower: $128.3 \mathrm{~s}$; cyclone: $100.2 \mathrm{~s}$ ) and second (variance, tower $18994 \mathrm{~s}^{2}$; cyclone $14269 \mathrm{~s}^{2}$ ) moments are not very good parameters to describe the distribution.

\section{CONCLUSION}

In earlier investigations (soon to be published) we have measured the residence time distribution of the drying air and have produced a qualitative description of the air flow. The residence time distributions as presented in this paper differ considerably from the residence time distribution of the drying air. (The space-time $\tau$ of the drying air is approximately $30 \mathrm{~s}$.) This may be caused by product deposition on the wall. We are currently investigating this phenomenon in more detail.

The flow in the dryer was found to consist of a fast flowing central core and large circulations around that core, more or less similar to the results found by Oakley et al ( 7 ) in the low-swirl regime. As the feed is being sprayed into the core some particles will be dragged along in the core. This explains the observation that the tracer concentration in the product streams starts to rise immediately after the injection.

\section{NOTATION}

$c_{i} \quad$ concentration tracer in sample $i$

$m_{i} \quad$ weight of sample $i$

$t_{i}$ time at which sample $i$ was taken.

$p \quad$ percentile

$n \quad$ number of samples ( $t_{n}$ is supposed to be at infinity)

$\tau \quad$ space time, defined as $\tau=\frac{V}{F}$

$V \quad$ volume of the drying chamber

$F \quad$ volumetric air flowrate. 


\section{LITERATURE CITED}

1. Masters, K. 1985. Spray Drying Handbook. Longman Scientific \& Technical, Essex

2. Place G., Ridgway K. and Danckwerts P.V. 1959. Investigation of air-flow in a spray dryer by tracer and model techniques. Trans. IChE (55), 114-121

3. Keey, R. B. and Pham 1977 Q. T. Residence-time distribution of air in a tallform spray chamber. Chem. Eng. Eng. Sci. (32), 1219-1226

4. Paris, J. R., Ross, P. N., Dastur, S. P., Morris, R. L. 1971 Modeling of the air flow pattern in a countercurrent spray-drying tower. Ind. and Eng. Chem., Proc. Des. and Dev. (10), 157-164

5. Ade-John, A. O., Jeffreys, G. V. 1978 Flow visualization and residence time studies in a spray drier Trans. Inst. Chem. Eng., 56(1), 36-42

6. Pham, Q. T., Keey, R. B. 1977 Some experiments on the residence-time distribution of droplets in a cocurrently worked spray chamber. Can. J. Chem. Eng., 55(4), 466-70

7. Oakley, D., Bahu, R., Reay, D. 1988 The aerodynamics of co-current spray dryers. Proc. 6th International Drying Symposium, Vol. 1, Versailles 